DOI

\title{
РАННЯ ДІАГНОСТИКА АЛКОГОЛЬНОЇ ЗАЛЕЖНОСТІ В ПРАКТИЦІ СІМЕЙНОГО ЛІКАРЯ
}

\author{
ОІ. К. Сосін, І. М. СКвіра, В. М. Міцура, Ю. Ф. Чуєв, О. Ю. Гончарова \\ Харківська медична академія післядипломної освіти
}

РЕЗЮМЕ. Рання діагностика алкогольної залежності є однією з найважливіших і найактуальніших завдань сучасної наркології. Залучення до вирішення цієї проблеми лікарів сімейної практики дозволить на етапі обстеження пацієнтів з гепатопатичною патологією виявити потенційну когорту осіб, які мають симптоми алкогольної залежності. Своєчасна консультація лікаря нарколога дасть можливість підтвердити або виключити наявність наркопатології, визначити лікувальну програму. Обстежено 255 пацієнтів з гепатопатичними розладами, які звернулися за медичною допомогою в загальносоматичні лікувальні установи. На основі даних клінічного інтерв'ю, психодіагностичного тестування, лабораторного дослідження розроблено комплексний алгоритм виявлення алкогольної залежності у пацієнтів з хронічними захворюваннями печінки.

КЛЮчОВІ СЛОВА: рання діагностика, алкогольна залежність, сімейний лікар.

Вступ. Рання діагностика синдрому алкогольної залежності (АЗ) є однією з найактуальніших проблем сучасної наркології, а своєчасне встановлення діагнозу належить до компетенції виключно лікаря нарколога. Ця проблема ускладнюється тим, що довгий час пацієнти заперечують наявність постійної алкоголізації, уникають вмотивованої консультації у лікаря-нарколога, вважаючи, що в будь-який час можуть самостійно відмовитися від зловживання алкоголем [1, 2]. Індикатором наявності АЗ стають ураження печінки (фіброз, гепатит, цироз), яка $є$ основною мішенню токсичного впливу тривалої інтоксикації. У цьому зв'язку рання діагностика початкових симптомів залежності за ступенем тяжкості алкоголь-асоційованихуражень печінки досить часто стає можливою при зверненні такого пацієнта до лікарів-інтерністів (сімейний лікар, терапевт, хірург, гастроентеролог тощо) 3 приводу виключно соматичних скарг, що маскують базову наркопатологію [3-5]. Подібні тренди перебігу сучасних форм АЗ і питання своєчасної їх діагностики не залишилися непоміченими у науковій наркології [6]. На кафедрі наркології ХМАПО (зав. кафедри проф. Сосін І. К.) був розроблений цикл тематичного удосконалення для лікарів загальносоматичної мережі "Діагностика станів сп'яніння», метою якого стало навчання сімейних лікарів концептуальних аспектів ранньої діагностики станів залежності в наркології, виявленню постінтоксикаційних уражень соматичної сфери на основі аналізу даних біохімічного моніторингу ферментної активності печінки, особливостей збору анамнестичних даних, застосування методів клінічного інтерв'ю та додаткових психодіагностичних тестів.

Мета дослідження. Розробити комплексний алгоритм ранньої діагностики АЗ у пацієнтів з хронічними захворюваннями печінки, які звертаються за медичною допомогою до сімейного лікаря в загальносоматичній мережі.
Матеріал і методи дослідження. Обстежено 255 пацієнтів з гепатопатичними розладами, які звернулися за медичною допомогою до сімейного лікаря загальносоматичної мережі у зв'язку 3 наявністю скарг на больові розлади та явища фізичного дискомфорту в ділянці шлунка. Пацієнти (83 жінки і 172 чоловіки) були у віці від 29 до 65 років (середній вік $(47,9 \pm 3,2)$ року). У структурі скарг переважала вісцеральна симптоматика (гепатоалгії, гастралгії, нудота, блювання, метеоризм, рідкі випорожнення, субіктеричність склер, тахікардія, задишка тощо).

Усім хворим проводили клініко-лабораторне обстеження, особливий акцент робили на аналізі біохімічних досліджень крові (загальний білірубін, тимолова проба, АСТ - аспартатамінотрансфераза, АЛТ - аланінамінотрансфераза, $\gamma$-ГТП - гаммаглутамілтранспептидаза, ПТІ - протромбіновий індекс, співвідношення АСТ/АЛТ, лужної фосфатази (ЛФ), холестерину (ХC), середній корпускулярний обсяг еритроцита (CKOE або MCV). При трактуванні результатів CKOE нижче 80 фл розглядали як мікроцитоз, а величину вище 100 фл інтерпретували як макроцитоз. При зловживанні алкоголем завжди наявний макроцитоз. Необхідно пам'ятати, що при встановленні діагнозу АЗ параклінічні дані $є$ допоміжними, головними ж $\epsilon$ клінічні діагностичні критерії.

Психодіагностичне обстеження на наявність симптомів АЗ проводили з використанням тестів MAST і CAGE. Мічиганський алкогольний скринінгтест (Michigan Alcoholism Screening Test, MAST) не дозволяє повністю дисимілювати реакцію на питання тесту. Тест CAGE (Cut, Annoyed, Guilty, Eyeopener) найбільшою мірою враховує особливості ставлення до алкоголю.

Усіх хворих після отримання інформованої згоди спрямовували на консультацію до лікарянарколога. 
Огляди літератури, оригінальні дослідження, погляд на проблему

Результати й обговорення. На першому етапі дослідження при появі у сімейного лікаря підозри на алкоголь-індуковану хворобу печінки проводили співбесіду, яка повинна була стимулювати хворого до комплайенсного саморозкриття. При наявності згоди хворий тестувався за допомогою тестів CAGE і MAST. Результати тестів CAGE (3 або 4 бали) і MAST (5 балів або більше) вказували на високу ймовірність наявності синдрому АЗ. Подальший лікарський огляд і інтерв'ю були спрямовані на уточнення клінічних ознак і оцінку діагностичних критеріїв АЗ. У деяких випадках інтерв'ю необхідне було і при негативних результатах тестів, якщо були підозри на нещирість пацієнта.

Оцінка лабораторних показників дозволила визначити роль алкогольного чинника у пошкодженні печінки. Так, підвищення $\gamma$-ГТП і трансаміназ (АЛТ, АСТ) вказувало на його провідну роль у загостренні хронічного захворювання печінки та на факт постійного вживання пацієнтом спиртного. Найхарактернішими для діагностики АЗ вважали наступні показники: підвищення $\gamma$-ГТП, перевищення $\gamma$-ГТП над АЛТ, підвищення АСТ, перевищення АСТ над АЛТ. Відповідно до проведеного нами дослідження, на користь наявності АЗ свідчать (в порядку зменшення діагностичної цінності): $-\gamma$-ГТП >3, 4 норм; - СКОЕ > 94фл; $-\gamma$-ГТП/ АЛТ $>1 ;-$ АCТ/АЛТ $>1 ;-$ АCТ $>2$ норм.
У 202 пацієнтів було проведено тест СAGE, який показав наступні результати: 0 балів було отримано у 66 хворих (32\%), 1 бал - у 35 (17,5\%), 2 бали - у 31 (15,5\%), 3 бали - у 45 (22,5\%), 4 бали - у 25 осіб (12,5\%). Таким чином, у 70 пацієнтів (35\%) тест виявився позитивним (3 або 4 бали). У 144 хворих застосовували тест MAST. Результати тесту: від 0 до 2 балів - у 62 (43,1 \%), від 3 до 5 балів-у 36 (25\%) пацієнтів, позитивний тест: 6 балів і більше - у 46 хворих (32\%). Порівнювали результати тестів CAGE і MAST. У 17 пацієнтів $(11,8 \%)$ результати тестів не збіглися: у 13 позитивним був лише тест CAGE, у 4 - тільки MAST. Частка хворих відмовилися від психодіагностичного обстеження, бо вони дійсно не мали ознак залежності.

Враховуючи результати тестів CAGE і MAST в сукупності з даними анамнезу (включаючи дані попередніх госпіталізацій, бесід з родичами), клінічними даними (наявність абстинентного синдрому, алкогольного делірію, ознак хронічної алкогольної інтоксикації тощо), даними консультації нарколога виявляли осіб з АЗ. Пацієнти були поділені на 2 групи: I група - 165 осіб без ознак АЗ (72 жінки, 83 чоловіки), і II група - 90 осіб з ознаками АЗ (11 жінок, 79 чоловіків). Алгоритм лікарської тактики при підозрі на АЗ наведено на схемі (рис. 1).

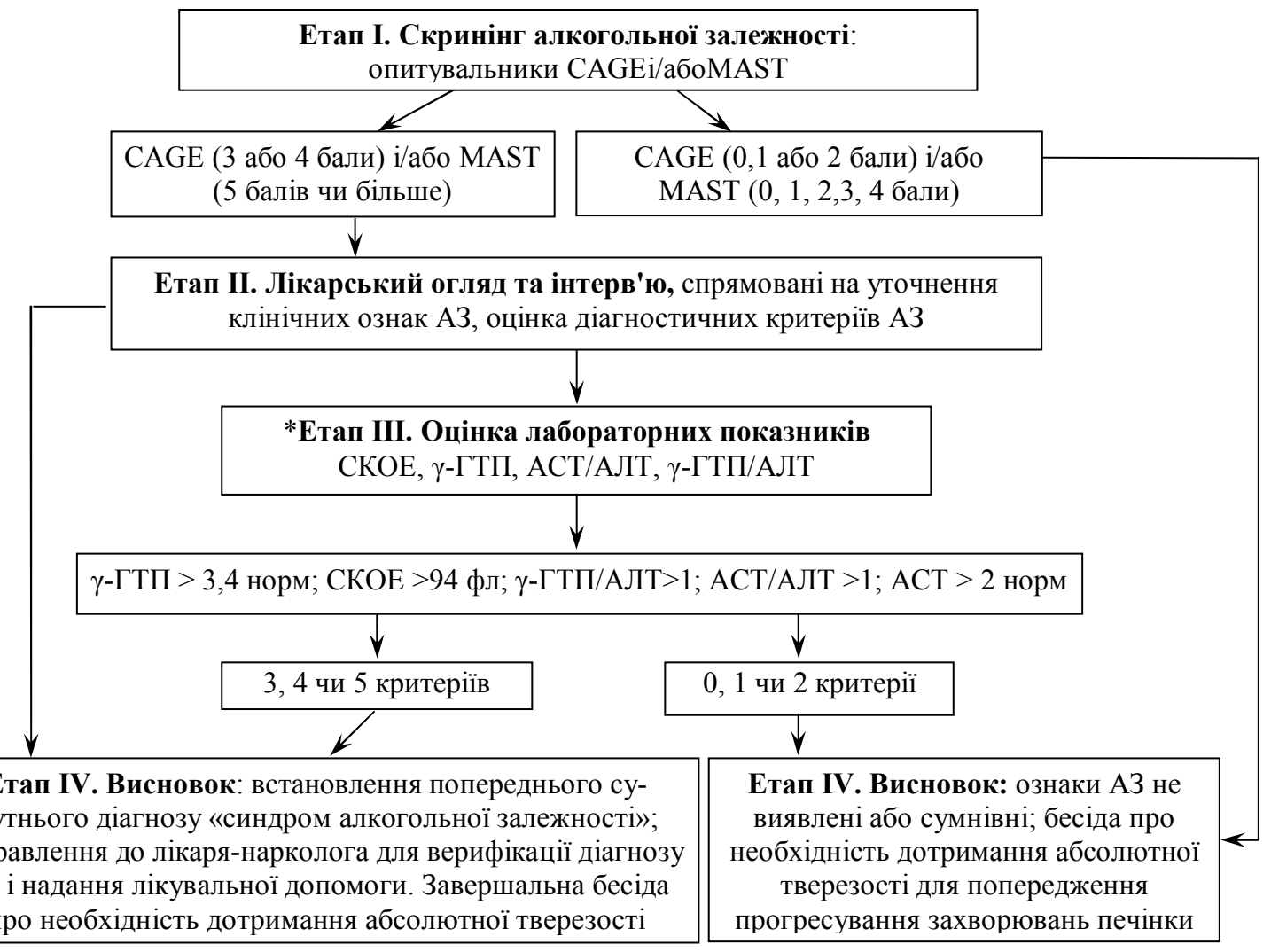

Рис. 1. Схема алгоритму виявлення алкогольної залежності у пацієнтів з хронічними захворюваннями печінки. 
Огляди літератури, оригінальні дослідження, погляд на проблему

Прогностично більш значущим слід визнати тест CAGE (3 або 4 бали). Тест MAST можна вважати позитивним при результаті 5 і більше балів. 3 обговорення відповідей на запитання тестів можна почати бесіду з пацієнтом про його ставлення до алкоголю.
Далі в I і II групах проводили порівняння біохімічних показників загального білірубіну, тимолової проби, трансаміназ (АЛТ, АСТ), співвідношення АСТ/АЛТ, лужної фосфатази (ЛФ), $\gamma$-ГТП, холестерину (XС), CKOE (табл. 1).

Таблиця 1. Порівняння лабораторних показників у пацієнтів в I і II груп

\begin{tabular}{|l|c|c|c|}
\hline \multicolumn{1}{|c|}{ Показники } & I група $(\mathrm{n}=165)$ & $\mathrm{II}$ група $(\mathrm{n}=90)$ & $\mathrm{p}$ \\
\hline Загальний білірубін, мкмоль/л & $12,8(9,2-18,7)$ & $22,2(12,1-84,3)$ & $<0,0001$ \\
\hline Тимолова проба, од. & $5,1(2,4-8,2)$ & $6,1(3,4-11,3)$ & 0,047 \\
\hline АЛТ, мккат/л & $1,07(0,81-1,60)$ & $1,31(0,87-1,95)$ & 0,088 \\
\hline АЛТ/N & $1,81(1,38-2,70)$ & $1,95(1,37-2,91)$ & 0,431 \\
\hline АСТ, мккат/л & $1,02(0,76-1,46)$ & $1,77(1,11-2,72)$ & $<0,0001$ \\
\hline АСТ/N & $1,52(1,13-2,18)$ & $2,63(1,66-4,06)$ & $<0,0001$ \\
\hline АСТ/АЛТ & $0,85(0,69-1,04)$ & $1,21(0,88-1,68)$ & $<0,0001$ \\
\hline ЛФ, од/л & $198,2(142,8-253,5)$ & $258,6(167,8-369,6)$ & $<0,0001$ \\
\hline ү-ГТП, од/л & $49,8(32,4-86,9)$ & $249,0(62,5-492,2)$ & $<0,0001$ \\
\hline ү-ГТП/N & $1,18(0,76-2,13)$ & $5,30(1,47-10,84)$ & $<0,0001$ \\
\hline ү-ГТП/АЛТ & $0,66(0,39-1,14)$ & $2,06(0,86-5,06)$ & $<0,0001$ \\
\hline ХС, Ммоль/л & $4,0(3,2-4,5)$ & $4,2(3,7-5,4)$ & 0,003 \\
\hline ПТІ & $0,73(0,67-0,79)$ & $0,70(0,60-0,78)$ & 0,025 \\
\hline СКОЕ, фл & $88,1(83,7-93,7)$ & $95,9(91,2-105,50)$ & $<0,0001$ \\
\hline
\end{tabular}

У групі хворих, які мають АЗ, ураження печінки було більш вираженим: показники білірубіну, тимолової проби, АСТ і співвідношення АСТ/АЛТ, $\gamma$-ГТП, ЛФ, ХС виявилися значно вищими, ніж у групі контролю, а протромбіновий індекс (ПТІ) - значно нижчим. Це підтверджує можливість їх використання для діагностики алкогольної залежності у хворих з гепатопатичною патологією. Рівні АЛТ значно не відрізнялися.

Висновки. Використання запропонованого алгоритму обстеження хворих у практиці сімейного лікаря з застосуванням клінічного, психодіагностичного та лабораторного досліджень дозволяє виявити проблеми, пов'язані з вживанням алкоголю, які потребують обґрунтованої консультації нар-

\section{ЛITEPATУРA}

1. Наркологія : національний підручник / під редакцією Сосіна І. К., Чуєва Ю. Ф. - Харків : Видавництво «Колегіум», 2014. - 1500 с.

2. Діагностика і терапія психічних та поведінкових розладів внаслідок вживання психоактивних речовин. Посібник для лікарів / О. І. Мінко, І. В. Лінский, О. С. Самойлова [та ін.]. - Харків : Плеяда, 2009. - 108 с.

3. Тарасова О.И. Современные лабораторные маркеры употребления алкоголя / О. И. Тарасова // Клиническая фармакология и терапия. - 2007. - Т. 16, № 1. C. 1-5.

4. Павлов А. И. Лабораторная диагностика интоксикации алкоголем у лиц с алкогольной болезнью печени / А. И. Павлов // Российский журнал гастроэнтеро- колога. Виявлено, що у хворих, які мають залежність від алкоголю, ураження печінки було більш вираженим: показники білірубіну $(22,2 ; \mathrm{p}<0,0001)$, тимолової проби $(6,1 ; p<0,047), А С Т(1,77 ; p<0,0001)$, і співвідношення АСТ/АЛТ $(1,21 ; p<0,0001), \gamma$-ГТП $(249,0 ; p<0,0001)$ ЛФ (258,6; $\mathrm{p}<0,0001)$, ХС (4,2; $\mathrm{p}<0,003)$ виявилися значно вищими, ніж у групі контролю, а ПТІ - значно нижчим $(0,70 ; p<0,0025)$. Це підтверджує можливість їх використання для діагностики алкогольної залежності.

Перспективи подальших досліджень. Отримані результати клінічного дослідження дозволяють провести поглиблене дослідження застосування даного алгоритму виявлення алкогольної залежності у хворих з гепатологічною патологією в практиці лікарів-інфекціоністів, терапевтів.

логии, гепатологии, колопроктологии. - 2010. - № 1. C. 44-51.

5. Міщук В. Г. Поширеність поєднаного алкогольного ураження печінки та підшлункової залози: оцінка критеріїв ідентифікації/ В. Г. Міщук, К. М. Скоропад//Буковинський медичний вісник. - 2015. - Т. 19, № 1 (73). С. 108-112.

6. Патент 65396 Україна, МПК (2011.01) G01N 33/48 А61B 10/00. Спосіб інтегрованої діагностичної ідентифікації алкогольної залежності у загальносоматичній практиці // Сосін І. К. з співавт., заявник та патентовласник: Харківська медична академія післядипломної освіти. - ч 2011 04235; заявл. 07.04.2011; опубл. 12.12.2011, бюл. № 23. 
Огляди літератури, оригінальні дослідження, погляд на проблему

\section{EARLY DIAGNOSIS OF ALCOHOL DEPENDENCE IN FAMILY DOCTOR'S PRACTICE}

\section{@I. K. Sosin, I. M. Skvira, V. M. Mitsura, Yu. F. Chuyev, O. Yu. Honcharova} Kharkiv Medical Academy of Postgraduate Education

SUMMARY. Early diagnosis of alcohol dependence is one of the most important and urgent problems of modern addiction narcology. Attraction of family practice doctors to this problem allows them to identify potential cohort of persons with symptoms of alcohol dependence. Prompt medical consultation of narcologist will provide an opportunity to confirm or exclude the presence of narcopatology, determine the treatment program. The study involved 255 patients with hepatic disorders, seeking medical care in somatic hospitals. On the basis of clinical interview, psycho-diagnostic testing, laboratory research complex algorithm designed to identify alcohol dependence in patients with chronic liver diseases.

KEY WORDS: early diagnosis, alcohol abuse, family doctor.

Отримано 3.03.2016 